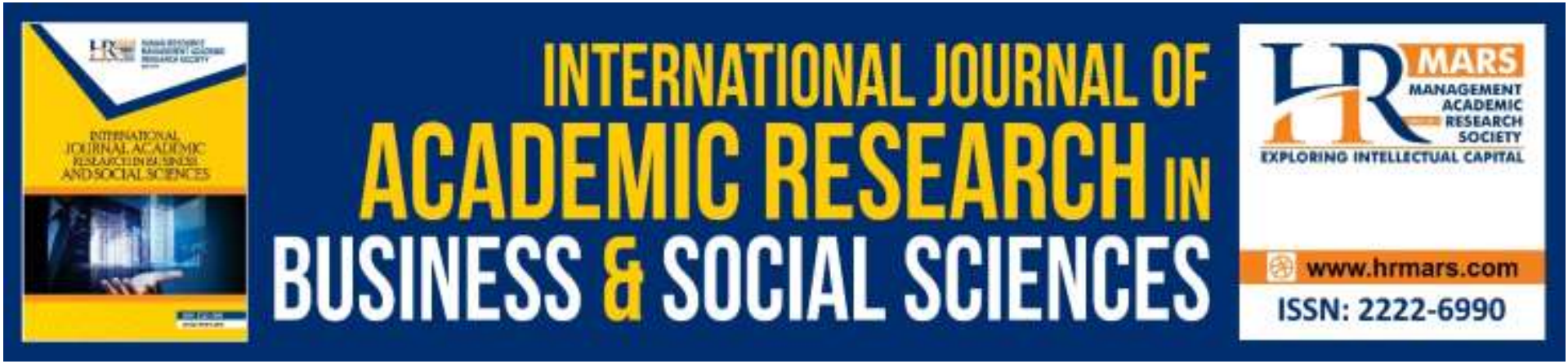

\title{
Challenges Facing Growth of Small Business: A Case of Ngongongare Village in Arusha, Tanzania
}

\author{
Neema Erasto Nzumbi, Lubotolo Misungwi
}

To Link this Article:http://dx.doi.org/10.6007/IJARBSS/v9-i10/6457

DOI: 10.6007/IJARBSS/v9-i10/6457

Received: 20 September 2019, Revised: 30 September 2019, Accepted: 01 October 2019

Published Online: 29 October 2019

In-Text Citation: (Nzumbi \& Misungwi, 2019)

To Cite this Article: Nzumbi, N. E., \& Misungwi, L. (2019). Challenges Facing Growth of Small Business: A Case of Ngongongare Village in Arusha, Tanzania. International Journal of Academic Research in Business and Social Sciences, 9(10), 67-82.

Copyright: (c) 2019 The Author(s)

Published by Human Resource Management Academic Research Society (www.hrmars.com)

This article is published under the Creative Commons Attribution (CC BY 4.0) license. Anyone may reproduce, distribute, translate and create derivative works of this article (for both commercial and non-commercial purposes), subject to full attribution to the original publication and authors. The full terms of this license may be seen

at: http://creativecommons.org/licences/by/4.0/legalcode

$$
\text { Vol. 9, No. 10, 2019, Pg. } 67 \text { - } 82
$$

Full Terms \& Conditions of access and use can be found at http://hrmars.com/index.php/pages/detail/publication-ethics 


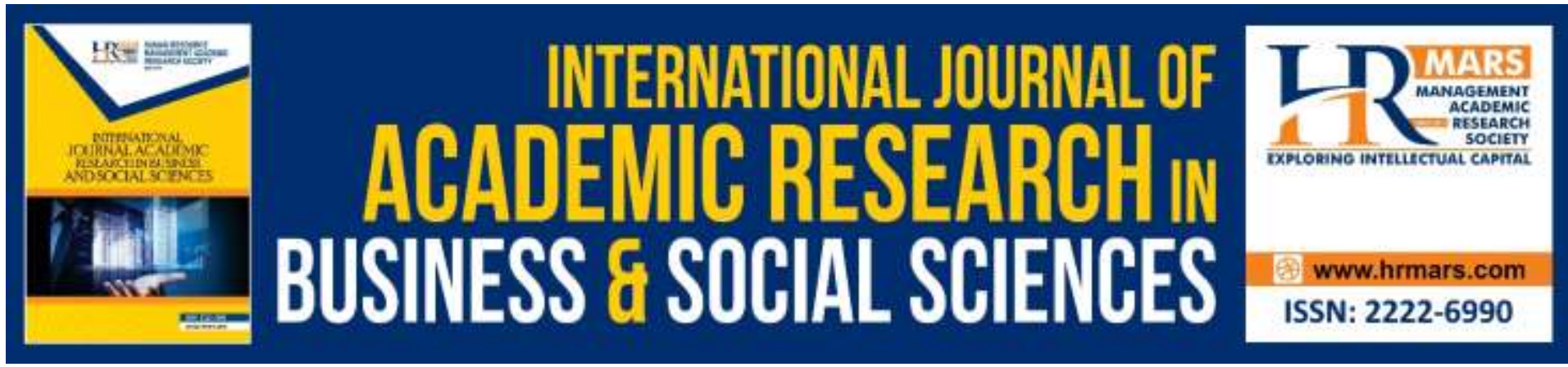

\title{
Challenges Facing Growth of Small Business: A Case of Ngongongare Village in Arusha, Tanzania
}

\author{
Neema Erasto Nzumbi, Lubotolo Misungwi \\ Tutorial Assistant, Assistant Lecturer, Faculty of Business, University of Arusha, Tanzania \\ Email: neemangussa2000@gmail.com
}

\begin{abstract}
This study investigated on challenges facing growth of small business at Ngongongare Village in Arusha, Tanzania. Through stratification and systematic random sampling procedures, 60 respondents filled the questionnaire which was validated through expert judgment. Reliability test yielded the Cronbach's Alpha of above 0.6 meaning the questionnaire was reliable for data collection. Data was analyzed through descriptive and inferential statistics to determine challenges that face growth of small businesses. The study concluded that loan accessibility was a major challenge that faced the growth of small businesses at Ngongongare Village. This was indicated by the fact that business owners depended on profit from their business source of capital. Lack of innovative skills to run business was another challenge that faced the growth of small businesses. This was due to the fact that small business owners did not have opportunities to attend workshops and seminars on how to run their businesses. Based on these conclusions, it is recommended that there is need to establish a SACCOS near Ngongongare Village and to educate small business owners on the importance of accessing loans from banks and other financial institutions instead of depending only on profit from their businesses as source of capital. Finally, the Faculty of Business at the University of Arusha should organize for regular workshops and seminars to small business owners that surround the university in order to instill knowledge on marketing strategies and how to run business effectively.
\end{abstract}

Keywords: Challenges, Growth, Business, Marketing, Technology, Financial, Ngongongare, Tanzania

\section{Introduction}

Small business growth can be defined as change in size during a determined time span (Dobbs \& Hamilton (2007). Penrose (2006) considers growth as an internal process in the development of an enterprise and an increase in quality and or expansion. Growth of Small Businesses is of prime importance for personal and national development. According to $\mathrm{Ma}$ and Lin (2010) in Bush (2016), small businesses have numerous benefits for national economic growth. Among others, small businesses contribute to the economic development of local markets and they are major performers in motivating the economy and expanding growth. Bamford and Bruton (2011) add that small business is critically important not just in the 
United States but also around the world whereby the World Bank estimates that one of the strongest factors in the growth of any nation's GNP is the presence of small size enterprises. The growth of the small businesses contributes to more opportunities like education and other welfare dynamics to business owners and the society at large. According to Nkonoki (2010), Tanzanian small businesses contribute significantly to employment creation, income generation and stimulation of growth to entrepreneurs in both urban and rural areas, and finally, development of the country as a whole economically, socially and even politically. Furthermore, small businesses create the economic, social and political growth in Tanzania.

Despite the fact that small businesses have a significant contribution to individuals, community and national development and that it is an important driver of the economic success of a community, a region and a state (Bamford and Bruton (2011), studies have indicated that many small businesses do not survive beyond five years (Bush, 2016). Turyahikayo (2015) conducted a study about challenges faced by small and medium enterprises in raising finance in Uganda. He brought to view the fact that in the country, over $50 \%$ of all SMEs close shop before they celebrate their second birth day. Whereas the collapse of these businesses has been attributed to their lack of ability to raise finance, little attention has focused to other challenges these businesses faced in trying to raise finance and how the challenges can be mitigated. He found that major challenges that face small businesses include, but not limited to inadequate collateral to secure loans, information opaqueness, low level technical and management skills, lack of professionalism, competition as well as inability to afford long term financing which in other words can be referred to as financial growth.

Studies have indicated potential challenges that may threaten growth of small businesses in various countries. While finance is one of the most important resources needed to start and develop enterprises (Turyahikayo, 2015), financial sustainability is a key component for the success of any business, thus becoming of great concern to researchers and business people. According to Aza (2017), one of the important issues that have recently captured the attention of researchers is the financial sustainability of microfinance institutions due to its importance in the livelihood of such microfinance institutions. According to Tucker and Miles (2004) in Aza (2017), financial sustainability is a program capacity to remain financially viable in the absence of domestic subsidies or foreign support. Ofriyie (2015) adds that financial sustainability is a situation when an institution covers all transaction costs with return on equity and consequently functions without subsidies. Kamunge, Njeru and Tirimba (2014) conducted a study in Kenya and found that there has been a growing concern and interest by the government and development agencies for the improved performance and growth of the small and medium entrepreneurs. Chuthamas, Islam, Keawchana and Yusuf (2011) conducted a study in Thailand on Factors Affecting Business Success of Small and Medium Enterprises and found that business' success is linked to various factors like survival, profit, return on investment, sales growth, number of people employed, asset purchases obtained from business, happiness and reputation.

Fouad (2013) conducted a study in Egypt on how Performance of Small and Medium Enterprises in Cairo affects growth opportunities and found that the benefit of sharing skills related to business for the owners or managers strengthen the future survival and eventual growth in various ways. Therefore, owners of the business should share information with 
managers and employees in order to make achievement and growth from the business. Kristiansen (2003) conducted a study on Linkages and Rural Non-Farm Employment Creation, particularly on challenges and policies and found that social network consists of a series of formal and informal ties between the central actor and other actors in a circle of acquaintances and represents channels through which entrepreneurs get access to the necessary resources for business start-up, growth and success. According to Kusi, Opata and Narh (2015), limited formal education, access to and use of new technologies, market information and access to credit from the banking sector are key challenges that may hinder growth of a business. Penrose (1959) offered some strong principles governing the growth of firms and the rate at which firms can grow successfully. Business owners should therefore, follow the principles and regulations of business on how to expand the business. Furthermore, Growth of small business depends on business owners' factors and internal control. According to Pollinger et al (2007) in Gashayie and Singh (2014), financial sustainability is one of key factors that can affect growth of a business. He defines sustainability as the ability to cover annual budgets including grants, donations and other fundraising. He further defines budget as a tool of business management and maintains that financial growth indicates that income from the microfinance services should be greater than the cost of providing services. He further advises that income from the microfinance services should be greater than the cost of providing services.

While small businesses face challenges across the globe, Tanzania is not exceptional. In Tanzanian context, small business enterprises are estimated to contribute $30 \%$ to $35 \%$ of the gross domestic product (Massawe, 1999) in Kelya (2016). Mfaume and Leonard (2004) conducted a study on Small Business Entrepreneurship in the country and came up with the findings that entry into small business entrepreneurship is not a problem as one can start small business at any time and in any place but the issue is that the established businesses are not sustainable due to various reasons. According to National Baseline Survey Report (2012), there are more than three million small businesses in Tanzania, most of which are engaged in trade and service sectors. The manufacturing sector, which is a core driving force for industrial development, accounts for only $13.6 \%$. Another distinctive feature of the sector is a huge number of informal operations. This situation suggests that there is a lot to be done in the sector to make its vibrant contributor to the economic and social wellbeing of Tanzanians. According to Citizen Reporter (2015), however, most of the micro enterprises in the country collapse before they start making profit due to lack of financial support.

Nkonoki (2010) conducted a study in Tanzania on factors limiting the success and/or growth of small business and found that business management skills in the firm create achievement of strategic planning and growth of the business. Kazimoto (n.d) conducted a study in Tanzania on factors affecting small businesses' performance and found that during the early stages of starting business many owners commit themselves to taking sources of finance they have available to them. The best source of finance to small business is family and friend's contributions, personal income or individual contributions from their pockets, loans, grants, partnership and donations. Like many parts of Tanzania, Ngongongare Village is full of small business men and women who operate different types of business including Kiosks, Stationeries, Hair salon, Butcher, Small shops, Canteen, Fruits and vegetables and grinding machinery. In the Ngongongare Village there are exists of the University of Arusha with the population of not less than 1600 students and workers. These are potential customers to 
small businesses, an advantage which can stimulate rapid growth of such businesses owners, yet the growth of the small businesses has been quite challenging. While reason to this trend are not known, the present study seeks to investigate on challenges facing growth for small business owners in Ngongongare Village with the hope that recommendations given by the researcher will make significant contributions to the field of finance and accounting.

\section{Review of Rerated Literature and Studies}

This section discusses potential challenges that face operations of small businesses from global to local perspective. It begins with general overview on growth of small businesses and then moves into marketing challenges, financial challenges and technological challenges.

\section{Growth of Small Business}

Studies have indicated the importance to have small business for national development. According to Bush (2016), for instance, small businesses are essential to the growth and sustainability of the economy. He quotes Hunter (2011) who argues that small enterprises managers need to evaluate risks and challenges and come up with strategies that will help to curb the potential challenges that may hinder the effectiveness of their businesses. Meher and Ajibie (2018) argue that small businesses are vital contributors to the overall performance of an economy, playing a crucial role in developing the economy and in creating employment, which do not only provide employment and income opportunities to a large number of people, but also are at the forefront of technological innovations and export diversification. Therefore, it is important to encourage citizens to engage into small businesses in order to propel economic growth of the country.

Nkonoki (2010) conducted a study in Tanzania on factors limiting the success and/or growth of small businesses and found that in Tanzania small businesses contribute significantly to employment creation, income generation and stimulation of growth in both urban and rural areas. However, According to Dinka (2019), it is not easy to bring sustainable growth and benefit from small business sectors until critical challenges are identified and solved. Therefore, for small business to bring profitability, there are potential challenges which must be overcome. This study therefore deals with marketing challenges, financial challenges and technological challenges that may hinder growth of small scale businesses in Tanzania.

\section{Marketing Challenges}

While there are numerous challenges that face small businesses, marketing is one of the key challenges. This is indicated by study findings of Karanja, Muturı, Mukab, Kabata, Wahome and Kayogo (2013) on small business management that small businesses face various challenges especially in areas of marketing, accounting, finance and management. Marketing is a tool for small business growth. Therefore, attending seminar/ workshop about marketing strategies helps the business to attract potential customers who purchase regularly. A small business owner therefore requires good marketing approaches involving purchasing activities, manufacturing the products, distribution and sales skills for business growth and performance. Capabilities required for business growth can be summarized in terms of marketing, management and profit (Brush et al. 2016). Shafeek (2009) conducted a study in Eastern Cape on enhancing the strategy for developing small business growth and found that marketing is the functional area that links the products or services of a business to its customers. Marketing plays a significant role in the success of small business where customers 
and suppliers link with products and services that fit the potential buyers of the business. However, marketing is the main challenge that faces business operations to small businesses. Therefore, lack of marketing skills may lead to failure of the business.

Bouazza1, Ardjouman and Abada (2015) conducted a study in Algeria on establishing the factors affecting the growth of small and medium-sized enterprises and found that marketing skills are considered as the most effective factor to firm survival and growth. Brush (2016) conducted a study on pathways to entrepreneurial growth with emphasis on the influence of management, marketing, and profitability. In this attempt, they defined growth of a business as geographical expansion, increase in the number of branches, inclusion of new markets and clients, increase in the number of products and services, fusions and acquisitions.

The macroeconomic factors such as on capital market tip to financial crisis in the market as a whole on interest rate, exchange rate, inflation, depression, unfavorable weather condition, changes of rules and regulations of the government, changes of policies of business in country and political instability.

\section{Financial Challenges}

Apart from marketing, financial factor is one of the major components for a successful business. According to Ofriyie (2015), financial sustainability is a situation when institutions cover all transaction costs with return on equity and consequently functions without subsidies. The main objective of the business is to maximize profit and to minimize costs to avoid unexpected risks. Borrowing of loan and equities in the small business covers business operating activities. Small business should own their assets at optimal level not too much on debts and not too much on equities. Optimal debts of assets should be ratio not too much or hanging without working. Therefore shareholder and owner of the business should manage dividend of the business.

Small business can successfully sustain only when the capital is sufficient. While some business owners may raise money from various sources like loans as capital, others may access capital through personal savings and other sources. According to Pollinger et al (2007) in Gashayie and Singh (2014), financial sustainability is the ability to cover annual budgets including grants, donations and other fundraising.

Capital is an important factor for an enterprise to run day-to-day operations, an investment to support financial sustainability and the business to grow. According Bush (2016), lack of enough capital is one of key challenges that may face small business sector. With this regard, Bush recommends that small business persons must struggle to maintain enough capital for running their business smoothly. He quotes Okpara (2011) and Muharremi et al. (2011) who link financial constraints with lack of sustainable capital. Finally, he identified lack of access to financing and long-term capital as the most important factors that hinder the success of small businesses. Significance of sustainable capital in small businesses is further brought to view by Meher and Ajibie (2018) who maintain that the financial sustainability depends on long term financial position which is an important indicator of financial performance.

\section{Technological Challenge}

Technology is another factor that may determine growth rate and sustainability of a business. Unless technology is integrated into the operation of business, the growth may not reach its 
full potential. With this regard, technological innovation skills are essential for effectiveness of small businesses growth. Therefore, business operators need to attend seminars and workshops to acquire technological skills for effective running of their businesses. The role of technology in business is indicated by Gartenstein (2018) who argues that it is difficult to run business systems without the use of technology. The essence of technology use in business is in that it is difficult to imagine operating even a small business without basic technology such as desktop computers for receiving emails and keeping records. Therefore, it is essential for operators of small businesses to keep records in computer and use internet and related services to enhance the quality of their business operation.

Studies have indicated the importance of technology in enhancing business operations. According to Qureshi, Khan and Schaeffer (2016, p. 8), for instance, "the interconnection between entrepreneurship and technology is valuable to distinguish the most applicable techniques for competitiveness in the business areas and supporting new ventures." They list other advantages of technology in business to include feasible development and growth toward Knowledge economy. Importance of technology in business is further explained by Pirzada and Ahmed (2013) who conducted a study on the effect of new technology on firm's business objectives, with a case of Pak-Suzuki Company. Among other findings, the researchers argued that technological machines make life easier. Particularly, with technology, people make fewer mistakes and time consumed in business plans is reduced. Further, technology brings the world closer together whereby information is shared quickly and efficiently through phones, internet and fax machines.

Dushyenthan (2013) conducted a study on usage of information communication technology and its effect on customer loyalty in Sri Lanka and revealed the importance of technology in business with the fact that among other benefits, information communication technology contributes significantly to customer loyalty and predicts greater rates for the growth of a business. According to Alford and Page (2014), adoption of technology for marketing is essential for the survival of small businesses. They bring to view the fact that technology has numerous advantages toward sustainability of small businesses. The use of Internet, for instance, has the potential to transform small enterprise marketing in a number of areas including customization, customer relationship marketing, access to new markets, businessto-business collaboration, co-creation of the product with customers and improving internal efficiency. Therefore, it is essential for operators of small businesses to use technological innovations for greater profitability and sustainable development of their business.

\section{Research Methodology}

This section discusses about the research methodology used in the study. It further explains the research design, population and sampling procedure and ethical consideration. The study employed survey research design.

\section{Research Design}

The survey research design is the procedures in quantitative research in which investigators administer a survey to a sample of the entire population of people to describe the attitudes, opinion, behaviors or characteristics of the population (Mugenda \& Mugenda, 2003). 


\section{Population and Sampling}

This study focused on small business owner population at Ngongongare Village in Arumeru District, Tanzania. The study employed stratified random sampling to determine the sample.. According to Ahuja (2003), stratified random sampling is the form of sampling in which the population is divided into a number of strata or sub-groups and a sample is drawn from each stratum. The researcher divided the respondents of Ngongongare Village into four strata namely Mamna, Ngurudoto, Napoko and Arauyo. Through systematic sampling, the researcher selected 15 respondents from each stratum to have 60 respondents in total to fill the questionnaire.

\section{Validity and Reliability}

Validity of research instrument means the instrument measures what it is supposed to measure. To establish the validity of the questionnaire, expert judgment was used. A team of research experts from the University of Arusha looked into the questionnaire against research questions and gave advice on how to improve it before data collection took place. The researchers incorporated all suggestions given then continued with data collection exercise. Reliability, on the other hand is defined by Gay, Mills and Airasian (2006) as the degree to which a study data consistently measure whatever they measure. The researcher carried a pilot study within Ngongongare Village to check the relevance and effectiveness of the questionnaire prior to data collection. Data was analyzed through Statistical Package for Social Science (SPSS) to establish acceptable reliability whereby the cut off point for acceptable reliability was .600 .

Table 1: Reliability Analysis Results

\begin{tabular}{llcc}
\hline SN & \multicolumn{1}{c}{ Variable in Question } & Cronbach's Alpha & Status \\
\hline 1. & Growth of Business & .911 & Reliable \\
2. & Financial Challenges & .676 & Reliable \\
3. & Marketing Challenges & .671 & Reliable \\
4. & Technological Challenges & .843 & Reliable \\
\hline
\end{tabular}

According to results in table 1, the Cronbach's Alpha for the Business Growth was .911, for Financial Challenges was .676, for Marketing Challenges was .671 and for Technological Challenges was.843. Therefore, it was concluded that the questionnaire was reliable for data collection.

\section{Ethical Considerations}

The researchers observed all ethical issues involved in research and publication. An ethical research committee from form the University of Arusha confirmed that the research instrument was ethically fit for data collection. Then permission was obtained from Ngongongare Village authority before the distribution of the questionnaire to the respondents took place. Anonymity and confidentiality were ensured in the questionnaire whereby respondents did not expose their names and were free to withdraw from filling the questionnaire. Finally, data was used only for intended purpose and not othe 


\section{Data Analysis, Interpretation and Discussions}

This part presents data, analyzes and discusses findings on challenges facing growth of small business owners in Ngongongare village. Discussion of results was enhanced by information from review of related literature and studies. This study had three research questions as follows:

1. What is the perception of small business owners in Ngongongare Village toward trends of their business?

2. What are challenges that face small business owners in Ngongongare Village?

3. Is there significant relationship between the growth of small business and the challenges that face the small business owners in Ngongongare village?

The first two research questions were analyzed through descriptive statistics in terms of mean scores while the third research question called for hypothesis testing and therefore was analyzed through inferential statistics. Therefore, data analysis is divided into descriptive and inferential statistics:

\section{Descriptive Analysis of Data}

The first two research questions were analyzed through descriptive statistics. The questionnaire had several items to which small business owners responded by ticking appropriate option ranging from 4- Strongly Agree, 3- Agree, 2- Disagree and 1- Strongly Disagree to indicate challenges that face their businesses. Statements in the questionnaire were stated in a positive way in that the mean score between 1.00 and 1.49 denoted strongly disagreement; between 1.50 and 2.49 denoted disagreement; between 2.50 and 3.49 denoted agreement and between 3.50 and 4.00 = strongly agreement. If respondents disagreed or strongly disagreed it was considered to be a challenge but if their either agreed or strongly agreed, it was considered not to be a challenge.

Research Question 1: What is the perception of small business owners in Ngongongare Village toward trends of their business?

Before looking into specific challenges that face the growth of small business in Ngongongare, it was essential to establish perception of respondents on trends of their businesses. In order to answer this research question, there were four items for growth of a business to which respondents were to indicate their level of agreement or disagreement with particular statements.

Table 2: Indicators for Business Growth

\begin{tabular}{|c|c|c|c|c|c|}
\hline SN & Item in the Questionnaire & Min. & Max. & Mean & Interpretation \\
\hline 1. & $\begin{array}{l}\text { My business has experienced an increase of new } \\
\text { purchases of assets }\end{array}$ & 1.00 & 4.00 & 3.28 & Agreed \\
\hline 2. & My business sales has experienced an increase in sales & 1.00 & 4.00 & 3.20 & Agreed \\
\hline 3. & $\begin{array}{l}\text { My business net profit has experienced an increase over } \\
\text { a period }\end{array}$ & 1.00 & 4.00 & 3.11 & Agreed \\
\hline 4. & $\begin{array}{l}\text { My business customer trends have experienced an } \\
\text { increase }\end{array}$ & 1.00 & 4.00 & 3.08 & Agreed \\
\hline
\end{tabular}


The mean score for all the four items in table two ranged between 2.50 and 3.49 denoting agreement. This means that small business owners considered their businesses to be experiencing an increase of new purchases of assets from time to time. They also believed that their business sales had experienced an increase in sales, their business net profit experiences an increase over a period and that their customer trends have experienced an increase. Therefore, respondents considered their businesses to be growing. This is something worth noting because small businesses are vital contributors to the overall performance of an economy, playing a crucial role in developing the economy and in creating employment, which provide employment and income opportunities to a large number of people (Meher and Ajibie, 2018).

Research Question 2: What are challenges that face small business owners in Ngongongare Village?

The financial, marketing and technological challenges that face growth of a business were measured by specific items in the questionnaire to which respondents were to indicate their level of agreement or disagreement as seen in table 3,4 and 5. These statements were stated in a positive way in such a way that if the respondents agreed or strongly agreed, the item was considered not to be challenges. But if they either disagreed or strongly disagreed, it was considered as a challenge.

\section{Financial Challenges}

While financial aspect is important for growth of a business, Table 3 indicates perception of small business owners toward financial challenges of business growth. As seen in the table, respondents agreed with the first three items that their capital is sufficient to attract potential customers, that their capital is sufficient to generate net profit from business operations and that the capital is sufficient to sustain their business operation. This is good to note because capital is a key determinant for a success of any business.

Table 3: Financial Challenges for Business Growth

\begin{tabular}{|c|c|c|c|c|c|}
\hline SN & Item in the Questionnaire & Min. & Max. & Mean & Interpretation \\
\hline 1. & $\begin{array}{l}\text { My capital is sufficient to attract potential customers to } \\
\text { my business }\end{array}$ & 1.00 & 4.00 & 3.26 & Agree \\
\hline 2. & $\begin{array}{l}\text { My capital is sufficient to generate net profit from my } \\
\text { business }\end{array}$ & 1.00 & 4.00 & 3.20 & Agree \\
\hline 3. & My capital is sufficient to sustain my business operation & 1.00 & 4.00 & 3.08 & Agree \\
\hline 4. & It is easy to get a loan for my business & 1.00 & 4.00 & 2.29 & Disagree \\
\hline 5. & $\begin{array}{l}\text { I have ever taken a loan from bank or any other financial } \\
\text { institution }\end{array}$ & 1.00 & 4.00 & 1.77 & Disagree \\
\hline 6. & Loan interest is affordable for my business & 1.00 & 4.00 & 1.75 & Disagree \\
\hline
\end{tabular}

However, respondents disagreed with the last three items in Table 3. Particularly, they disagreed that it is easy to get a loan for their businesses, they also disagreed that they have ever taken a loan from bank or any other financial institution to sustain their business, and that loan interest is affordable for their business. Therefore, accessibility to loan was considered to be a key financial challenge that faces the growth of small businesses at 
Ngongongare Village. This finding is in harmony with what Kazimoto (n.d) who conducted a similar study in Tanzania and found that the best source of finance to small business is family and friend's contributions, personal income or individual contributions.

\section{Marketing Challenges}

While marketing strategy is another important factor for growth and sustainability of a business, Table 4 indicates perception of small business owners toward marketing aspect of their businesses. As seen in the table, respondents agreed with the first four items in the questionnaire. Particularly, they agreed that it is easy for them to attract customers, that they practice discount and promotion strategies to maximize profit and attract customers and that they have customer networks to increase net profit in their businesses. This situation is worth noting because marketing strategy is very important for the growth of any business and customer attraction guarantees smooth running of a business. When Bouazza1, Ardjouman and Abada (2015) conducted a similar study in Algeria, they found that marketing skills should be considered as one of the most effective factors for a firm's survival and growth. Therefore, it is important to encourage small business owners to be creative and to continue using various marketing strategies to attract customers for business sustainability.

Table 4: Marketing Challenges for Business Growth

\begin{tabular}{llcccc}
\hline SN & \multicolumn{1}{c}{ Item in the Questionnaire } & Min. & Max. & Mean & Interpretation \\
\hline 1. & It is easy for me to attract new customers & 1.00 & 4.00 & 3.33 & Agree \\
2. & I have practiced discount strategy to maximize sales & 1.00 & 4.00 & 3.27 & Agree \\
3. & I have practiced promotion strategy in order to attract & 1.00 & 4.00 & 3.10 & Agree \\
& $\quad$ customer & 1.00 & 4.00 & 3.00 & Agree \\
4. I have customer network to increase net profit & 1.00 & 4.00 & 2.30 & Disagree \\
5. I have attended a seminar on marketing strategies & & & & &
\end{tabular}

However, respondents disagreed that they have attended seminars on marketing strategies for their business. This indicates that lack of opportunities to attend seminars and workshops on marketing strategies is a potential challenge that faces growth of small businesses at Ngongongare Village.

\section{Technological Challenges}

While technology is another important fact for success of a business, Table 5 indicates perception of small business owners toward technology and innovation aspect of business growth. As seen in the table, mean score for all items was between 1.50 and 2.49 denoting disagreement with the statements. Particularly, respondents disagreed that they have acquired innovative skills to introduce new products to their businesses and that they have acquired innovative skills to maximize sales of their business. 
Table 5: Technological/ Innovative Challenges for Business Growth

\begin{tabular}{llllll}
\hline SN & \multicolumn{1}{c}{ Item in the Questionnaire } & Min. & Max. Mean & Interpretation \\
\hline 1. I have acquired innovation skills to introduce new & 1.00 & 4.00 & 2.49 & Disagree \\
$\begin{array}{l}\text { products } \\
\text { 2. I have acquired innovative skills to maximize sales of my } \\
\text { business }\end{array}$ & 1.00 & 4.00 & 2.49 & Disagree \\
$\begin{array}{l}\text { 3 attend workshops to know on how to calculate net } \\
\text { profit }\end{array}$ & 1.00 & 4.00 & 2.18 & Disagree \\
$\begin{array}{l}\text { I have attended seminars to improve customer care to } \\
\text { my business }\end{array}$ & 1.00 & 4.00 & 2.08 & Disagree \\
\hline
\end{tabular}

They also disagreed that they attended workshops to gain knowledge on how to calculate net profit of their business and that they have attended seminars to improve customer care in their businesses. Therefore, this indicates that technological aspect is a key challenge that faces the operation small businesses at Ngongongare Village.

\section{Hypothesis Testing}

Having described perception of small business owners toward potential challenges that face the growth of their businesses, this section deals with hypothesis testing. The hypothesis emanates from the third research question below.

Research Question 3: Is there significant relationship between the growth of small business and the challenges that face the small business owners in Ngongongare village?

This research question called for testing of a hypothesis which states: There is no significant relationship between the growth of small business and the financial, marketing and technological challenges that face the small business owners in Ngongongare village.

Table 6: Factors Influencing Growth of a Business

\begin{tabular}{llllll}
\hline & & Growth & Financial & Market & Technology \\
\hline Growth & Pearson Correlation & 1 & $.334^{* *}$ & $.515^{* *}$ & $.271^{*}$ \\
& Sig. (2-tailed) & & .009 & .000 & .036 \\
\multirow{5}{*}{ Financial } & $\mathrm{N}$ & 60 & 60 & 60 & 60 \\
& Pearson Correlation & $.334^{* *}$ & 1 & .027 & $.318^{*}$ \\
& Sig. (2-tailed) & .009 & & .839 & .013 \\
\multirow{5}{*}{ Market } & $\mathrm{N}$ & 60 & 60 & 60 & 60 \\
& Pearson Correlation & $.515^{* *}$ & .027 & 1 & $.289^{*}$ \\
& Sig. (2-tailed) & .000 & .839 & & .025 \\
\multirow{3}{*}{ Technology } & $\mathrm{N}$ & 60 & 60 & 60 & 60 \\
& Pearson Correlation & $.271^{*}$ & $.318^{*}$ & $.289^{*}$ & 1 \\
& Sig. (2-tailed) & .036 & .013 & .025 & \\
& $\mathrm{~N}$ & 60 & 60 & 60 & 60 \\
\hline
\end{tabular}

**. Correlation is significant at the 0.01 level (2-tailed).

*. Correlation is significant at the 0.05 level (2-tailed). 
The hypothesis was analyzed through Pearson product Moment Correlation Coefficient. Nature of existing correlations between the variables would be either positive or negative and was interpreted based on the following criteria: $\geq .70=$ strong relationship, $\geq .50=$ moderate relationship and $\leq .50=$ weak relationship. With a Pearson Correlation of .334 (Sig. of .009), there is a weak yet positive correlation between financial aspect and business growth. Therefore, financial aspect positively influences the growth of a business. Furthermore, with a Pearson Correlation of .515 (Sig. of .000), there is a moderate yet positive correlation between growth of a business and marketing strategies. Therefore, marketing strategy is a determinant for a business to grow.

With a Pearson Correlation of .271 (Sig. of .036), there is a weak yet positive correlation between growth of a business and technological strategy. Furthermore, with a Pearson Correlation of .318 (Sig. of .013), there is a weak yet positive correlation between financial aspect and technology in business. Therefore, financial aspect influences availability of technological innovation for the business to grow. Lastly, with a Person Correlation of .289 (Sig. of .025), there is a weak yet positive correlation between technological aspect and marketing strategy. Therefore, technology is an important factor for effective marketing of a business

\section{Conclusions and Recommendations}

This part presents conclusions and then gives recommendation based on research findings regarding challenges facing the growth of small businesses at Ngongongare Village in Arusha.

\section{Conclusions of the Study}

Based on above summary of findings, the study came up with the following conclusions regarding challenges that face the growth of small business at Ngongongare Village.

1. Study findings brought to light the fact that owners of Small Businesses faced challenges in running their businesses. Particularly, accessibility to loan was a major challenge that faced the growth of small businesses at Ngongongare Village. This was indicated by the fact that majority of business owners depended on profit from their business a source of capital.

2. Another key challenge that was observed has to do with marketing aspect. Particularly, lack of innovative skills to run a business was another challenge that faced the growth of small businesses. This was due to the fact that small business owners did not have access or opportunities to attend workshops and seminars on how to run their businesses. Therefore, marketing is an important challenge that faced respondents.

3. Finally, inferential statistical test led the researchers to come up with a conclusion on interrelation among variables under investigation. Particurly, there is a positive correlation between growth of a business and such factors as financial stability, marketing strategies and technology factor. Therefore, effective financial aspect, marketing strategy and technological aspect are important factors for effective running of a business. 


\section{Recommendations of the Study}

Based on above conclusions of the study, the researcher gives the following recommendations with regarding to effective running of small businesses at Ngongongare Village:

1. There is need to educate small business owners on the importance of accessing loans from banks and other financial institutions instead of depending on profit from their businesses as key source of capital.

2. It is recommended that Faculty of Business at the University of Arusha should organize for regular workshops and seminars to small business owners who surround the university to gain knowledge on marketing and how to run their businesses effectively.

3. Since financial stability, marketing strategy and technological innovation are determinants for growth of small businesses, it is recommended that small business owners should strive to improve their marketing strategies and technological innovations through seminars and workshop attendance in order to increase the growth rates of their businesses.

\section{Theoretical and Contextual Contribution}

This study has made an immense contribution to various stakeholders in the field of Business Administration. First, study gap on importance of accessing loans for small business sustainability has been identified. This will help future researchers to come up with topics for further investigation. Secondly, awareness has been created to Department of Business, University of Arusha to realize challenges facing Small Business owners around the university. This will enable the University's Faculty of Business to prepare seminars and workshops that will benefit small business owners to increase sustainability. Finally, the study will benefit one of the researchers as partial fulfillment for graduating with Master o Business Administration in Accounting and Finance.

\section{Reference}

Alford, P., and Page, S. J. (2014). Marketing technology for adoption by small business. The Service industries Journal, 35(11-12), 655-669

Ahuja, R. (2003) Research Methods, Rawat Computer, Jaipur. India

Aza, I. E. (2017).Effect of Funding Structure on Financial Sustainability of Micro Finance Banks (MFBS), in Nasarawa State of Nigeria.Research Journal of Finance and Accounting, 8(24), 108-117

Bamford C.E and Bruton G (2011) Entrepreneurship, A Small Business Approach,New York; McGraw-Hill

Bouazza, A. B., Ardjouman D., and Abada, O. (2015) Establishing the Factors Affecting the Growth of Small and Medium-sized Enterprises in Algeria. American International Journal of Social Science (2), 101-115.

Bush, M. A. (2016). Strategies Affecting the Sustainability of Small Businesses. Walden Dissertations and Doctoral Studies.Walden University.

Bush, M. A. (2016). Strategies Affecting the Sustainability of Small Businesses.Doctoral Dissertation from Walden University. Retrievedfrom https://pdfs.semanticscholar.org/729c/6ba33d10311f784257ed3ab82e4f55e7e0b5. pdf. 
Brush, C. G., Ceru, D. J., \& Blackburn, R. (2009). Pathways to entrepreneurial growth: the influence of management, marketing, and money. Business Horizons, 52(5), 481-491. http://dx.doi.org/10.1016/j. bushor.2009.05.003.

The Citizen Reporter (2015). Study explains why Tanzania small businesses fail.Retrieved June 20/2019 from https://www.thecitizen.co.tz/News/Business/Study-explains-why-TZsmall-businesses-fail/1840414-2858322-01c099z/index.html

Chuthamas, C., Islam, A., Keawchana, T., and Yusuf, D. M. (2011) Factors Affecting Business Success of Small \& Medium Enterprises (SMEs) in Thailand, www.ccsenet.org/ass Asian Social Science $(7(5,180-190$.

Dinka, S. T. (2019) Assessment of Critical Challenges Facing Small Business Enterprises: A Survey of Small Businesses in Woliso Twon, Ethiopia 10(3), 23-25.

Dobbs, M., \& Hamilton, R. T. (2007). Small business growth: recent evidence and new directions. International Journal of Entrepreneurship Behaviour and Research, 13(5), 296-322. http://dx.doi. org/10.1108/13552550710780885

Dushyenthan. (2013). Usage of Information Communication Technology and Its Effect on Customer Loyalty. The Study Of Banking Industries In Jaffna Srilanka. (A Comparative Study Of State Banks \& Private Banks). Journal of Marketing and Consumer Research 1(2013), 59-68.

Fouad, M. A. A. (2013) factors affecting the performance of small and Medium enterprises(SMES) in the manufacturing sector of cairo, egypt, international journal of business and management studies 5(2), 157-166.

Gartenstein, D. (2018). The positive and negative effects of technology in business. Retrieved on October 15, 2019 from https://bizfluent.com/list-6943594-positive-negativeeffects-technology-business.html

Gashayie, A. and Singh, M. (2014). Relationship of financial Sustainability and Outreach in Ethiopian Microfinance Institutions: Empirical Evidence. Research Journal of Finance and Accounting, 5(17), 207-211.

Gay, L. R., Mills, G. E., \& Airasian, P. (2006). Educational research: Competences for analysis and interpretation ( $8^{\text {th }}$ ed.). New Jersey: Pearson.

Kamunge, M. S., Njeru, A., and Tirimba, O. I. (2014) Factors Affecting the Performance of Small and Micro Enterprises in Limuru Town Market of KiambuCounty, Kenya. International Journal of Scientific and Research Publications, 4(12),1-20.

Karanja, T., Muturi, P., Mukabi, M., Kabata, D., Wahome, S., and Kayogo, M. (2013) Small Business Management, PhD Students Pursuing Business Adminstration and Management specialising in Entreprenuership, DedanKımathi Unıversıty of Technology, School of Graduate Studies and Research, International Journal of Business and Social Science 4(16).

Kelya, S. A. (2016). Barriers to growth of Small Enterprises of Usa River Town in Arumeru District, Arusha region, Tanzania. MBA Dissertation, University of Arusha, Tanzania.

Kristiansen, S. (2003) Linkages and Rural Non-Farm Employment Creation: Changing Challenges and Policies in Indonesia. Rome

Kusi, A., Opata, C. N., and Narh, T. J. (2015) Exploring the Factors That Hinder the Growth and Survival of Small Businesses in Ghana (A Case Study of Small Businesses within Kumasi Metropolitan Area) authors and Scientific Research Publishing Inc.

Mfaume, R. M., and Leonard, W. (2004). Small Business Entrepreneurship in Dar essalaam Tanzania: Exploring Problems and Prospects for Future Development. South Africa: 
African Development and Poverty Reduction. Retrieved June 20/2019 from http://www.tanzaniagateway.org/docs/SME Tz Prbs_prospects.pdf

Meher, K. C., Ajibie, D. (2018). Financial Sustainability of SMEs by Injecting Debt Finance. The Management Accountant January (2018), 80-87.

Mugenda, O. M., Mugenda, A. G. (2003).Research methods: Quantitative and qualitative approaches. Nairobi: ACTS Press.

National Baseline Survey Report for Micro, Small, and Medium Enterprises in Tanzania. (2012). Retrieved on 20 June 2019 from http://www.fsdt.or.tz/wp content/uploads/2016/05/MSME-National-Baseline-Survey-Report.pdf

Nkonoki, E. (2010) What are the factors limiting the success and/or growth of small businesses in Tanzania? - An empirical study on small business growth, Arcada University of Applied Sciences International business

Ofriyie, A. P. (2015). Financial Sustainability Factors of Higher Education Institutions: A Predictive Model. International Journal of Education Learning and Development 2(3), 17-38.

Penrose, E. (1959). The theory of the growth of the firm, Revised edition published 2009. Oxford University Press.

Pirzada and Ahmed (2013). Effect of New Technology on Firms Business Objectives: A Case Study of Pak-Suzuki Company. International Journal of Business Administration 4(3), 95-101.

Shafeek, S. (2009) Enhancing the Strategy for Developing Small Growth Potential Firms in the Eastern Cape.

Turyahikayo, E. (2015). Challenges Faced by Small and Medium Enterprises li Raising Finance in Uganda. International Journal of Public Administration and Management Research 3(2), 21-33.

Qureshi, I. A., Khan, A., and Schaeffer, D. (2016). The role of technology entrepreneurship towards economic growth: an application of RFID in Livestock Sector of Pakistan. European Journal of Business and Management 8(4), 8-18. 